\title{
Follicle growth, ovulation rate, body weight change, and antioxidant and metabolic status in three fat- tailed sheep breeds fed a half-maintenance diet
}

This article was published in the following Dove Press journal:

Open Access Animal Physiology

6 October 2014

Number of times this article has been viewed

\author{
Amal M Abo El-Maaty' \\ Mohamed H Abd El-Gawad ${ }^{2}$ \\ 'Animal Reproduction and AI \\ Department, Veterinary Division, \\ National Research Centre, \\ Giza, Egypt; ${ }^{2}$ Animal Production \\ Department, Faculty of Agriculture, \\ Cairo University, Egypt
}

\begin{abstract}
This study aimed to determine the impact of feeding a half-maintenance diet on ovulation rate, metabolic status, and antioxidant status of three native breeds of fat-tailed sheep under Egyptian conditions. Estrus was synchronized with two doses of cloprostenol 11 days apart. The number of preovulatory follicles and corpora lutea were evaluated by transrectal ultrasound. Total antioxidant capacity, superoxide dismutase (SOD), alkaline phosphatase (ALP), lactate dehydrogenase (LDH), total cholesterol, insulin, and glucose were measured in serum. Breeds and treatments were used as fixed factors using univariate general linear model; within-treatment (control, restricted), simple one-way analysis of variance and within-breed, independent samples $t$-test were used. The results revealed significant effect of treatment $(P=0.001)$ and breed $(P<0.046)$ on ovulation rate. Glucose, total antioxidant capacity, and total cholesterol increased, but insulin decreased, due to the dietary restriction. LDH and SOD levels increased due to the dietary restriction. Restricted ewes had insignificantly decreased body weight, but the amount and percent of decrease compared to initial body weight was significantly high in restricted Rahmani ewes and low in Barki ewes. In conclusion, fat tail helped ewes of different breeds could withstand adverse nutritional conditions for 1 month with minimal effects on body weight, ovulation rate, and metabolic and antioxidant status.
\end{abstract}

Keywords: diet restriction, antioxidants, insulin, ewes

\section{Introduction}

The effect of nutrition on reproduction is well known, but the exact mechanisms and mediating factors affecting both static and dynamic changes still need further clarification. ${ }^{1}$ The physiological mechanisms that control energy balance are reciprocally linked to those related to reproduction. Hence, reproduction is susceptible to changes in fuel availability through a complex interaction of hormones and metabolites. ${ }^{2}$ Limited feed resources can reduce reproductive efficiency to an extent dependent upon the degree of feed restriction ${ }^{3}$ and body condition of the animals at the time of feed restriction. ${ }^{4}$

Ovulation rate is determined by the number of ovarian follicles developing into ovulatory stages in each estrous cycle, which is controlled by genetics and modified by exogenous inputs such as season, exogenous hormones, steroid hormones, and nutrition. ${ }^{5,6}$ Nutrition exerts a crucial influence on follicular growth and development, ${ }^{6}$ through changes in body weight and condition. ${ }^{7}$ Short-term undernutrition was shown to have deleterious effects on functionality of preovulatory follicles, which can compromise fertility. ${ }^{8}$

Insulin is a key hormone controlling glucose metabolism because it increases the ability of the cells to take up glucose, and an increase in blood glucose signals the
Correspondence: Amal M Abo El-Maaty Animal Reproduction and Al Department, Veterinary Division, National Research Centre, Tahrir Street, Dokki,

Giza 12622, Egypt

Tel +20 2 354I 5244;

+202012 21278132

Email amalaboelmaaty।@yahoo.com (c) (i) (2) $\odot 2014$ Abo El-Maaty and Abd El-Gawad. This work is published by Dove Medical Press Limited, and licensed under Creative Commons Attribution - Non Commercial (unported, v3.0) License. The full terms of the License are available at http://creativecommons.org/licenses/by-nc/3.0/. Non-commercial uses of the work are permitted
without any further permission from Dove Medical Press Limited, provided the work is properly attributed. Permissions beyond the scope of the License are administered by Dove Medical Press without any further permission from Dove Medical Press Limited, provided the work is properly attrbuted. Penn 
release of insulin from $\beta$-cells of the pancreatic islets. Insulin has specific effects on granulosa and theca cell function. ${ }^{9}$ Insulin is an important regulator of folliculogenesis because of either its general regulation of cellular glucose uptake or its direct action on folliculogenesis either way, suggesting a role for insulin in the mechanism of nutritional effects on folliculogenesis in sheep. ${ }^{10}$

Animals have developed mechanisms to cope with lean periods such that, when food is limited, resources are diverted from those physiological functions that offer no benefit for immediate survival (eg, reproductive capacity) to thereby support an increase in the maintenance functions that prolong life. Protein restriction seems to boost antioxidant defenses and inhibit the accumulation of oxidative damage as caloric restriction does. ${ }^{11}$ It was shown that food restriction decreased antioxidant parameters in liver and plasmatic malondialdehyde concentrations and increased total antioxidant status plasma concentrations when compared to the ad libitum situation. ${ }^{12}$ Sheep in Egypt are fat-tailed, including even the small desert Barki. Fat-tailed sheep breeds are known for their adaptation to nutritional stress, among other harsh production conditions. Since fat depot able to be mobilized under nutritional stress. ${ }^{13}$ Where, lipid was mobilized from the fat tails of sheep exposed to starvation in the form of free fatty acids. ${ }^{14}$

The purpose of this study was to determine effects of feeding a half-maintenance diet for 30 days on growth dynamics and competence of preovulatory follicles, ovulation rate, body weight, metabolic changes, hormonal, and antioxidant markers in synchronized mature fat-tailed cyclic Barki, Rahmani, and Ossimi ewes.

\section{Materials and methods}

The present study was carried out at the experimental farm of the Animal Production Department, Faculty of Agriculture, Cairo University, Giza, Egypt. Rahmani and Ossimi ewes are regular polyestrous all year round, while Barki ewes are seasonally polyestrous in their original habitat in the western desert, but became regular polyestrous when brought to the Nile Valley. This study was conducted from March to May, before the introduction of rams for breeding.

\section{Animals}

Multiparous Rahmani (3.2 years), Barki (3.7 years), and Ossimi (2.8 years) ewes were used for conducting this experiment. Ewes in each breed were divided into two treatments. Control ewes received the daily nutritional requirements for maintenance according to NRC. ${ }^{15}$
The restricted ewes in each breed were subjected to $50 \%$ diet restriction ( 0.5 maintenance nutritional requirements) for 30 days. Rahmani ewes $(n=20)$, Barki ewes $(n=20)$, and Ossimi ewes $(n=17)$ were all of average body weight (41.5 $\pm 1.1 \mathrm{~kg}, 38.7 \pm 1.1 \mathrm{~kg}$, and $42.9 \pm 1.8 \mathrm{~kg}$, respectively). Ewes were kept under normal daylight and temperature and were maintained in semi-shaded pens, where drinking water was freely accessible. Egyptian clover (berseem [Trifolium alexandrinum]), hay, a concentrate mixture (13\% CP and 0.65 $\mathrm{kg}$ total digestible nutrients [TDN]), and wheat straw were used in the diet formulation, according to the availability during the year. Fresh berseem and hay main analysis, minerals, and ruminant nutritive value were tabulated. ${ }^{16}$

\section{Experimental design and treatments}

In treatment 1 , control Barki $(n=10)$, Rahmani $(n=10)$, and Ossimi ( $n=9)$ ewes were subjected to the regular farm feeding regime $(0.25 \mathrm{~kg}$ concentrate feed mixture and $4 \mathrm{~kg}$ Egyptian clover) per head. Feed amounts were based on the maintenance requirements of ewes, representing $0.9 \mathrm{~kg}$ dry matter/ head/day (2.25\% of live body weight), and $0.48 \mathrm{~kg}$ TDN/ head/day. Treatment 2 comprised restricted Barki $(n=10)$, Rahmani ( $\mathrm{n}=10)$, and Ossimi $(\mathrm{n}=8)$ ewes subjected to a feedrestriction regime ( $50 \%$ of maintenance requirements). Each restricted ewe received $2.5 \mathrm{~kg}$ clover, representing $0.5 \mathrm{~kg}$ $\mathrm{DMI} / \mathrm{head} /$ day $(1.25 \%$ of live body weight), and $0.23 \mathrm{~kg}$ TDN/head/day (Table 1).

Feed chemical composition and tabulated nutritive value of offered feeds are presented in Table 2. Control and restricted ewes of each breed were kept in separate yards. Fifteen days after start of restriction, restricted and control ewes received two submucosal doses of $65 \mu \mathrm{g}$ cloprostenol (estroPLAN;

Table I Feed and nutrients intake/head of both experimental diets

\begin{tabular}{lll}
\hline Item & Control & Restricted \\
\hline $\begin{array}{l}\text { Feed intake, kg/head/day } \\
\quad \text { Clover }\end{array}$ & 4.00 & \\
$\quad$ CFM & 0.25 & 2.50 \\
Ration composition (DM basis) & & 0.00 \\
$\quad$ TDN, \% & 50.6 & \\
DCP, \% & 10.7 & 22.5 \\
Nutrients intake & & 5.00 \\
DM, kg/head/day & 1.03 & \\
DM, \% LBW & 2.56 & 0.50 \\
TDN, kg/head/day & 0.52 & 1.25 \\
DCP, g/head/day & 107 & 0.23 \\
ME, MJ & 1.88 & 50 \\
\hline
\end{tabular}

Abbreviations: CFM, concentrated feed matter; DM, dry matter; TDN, total digestible nutrients; DCP, digestible crude protein; LBW, live body weight; ME, metabolizable energy; MJ, megajoules. 
Table 2 Chemical composition and nutritive value of offered feeds used in ration formulation

\begin{tabular}{lll}
\hline Item & Clover & CFM \\
\hline Chemical composition, \% DM basis & & \\
DM & 20.00 & 89.20 \\
Organic matter & 86.42 & 96.16 \\
Crude protein & 18.22 & 14.11 \\
Crude fiber & 6.9 & 8.51 \\
Ether extract & 4.17 & 4.20 \\
Nitrogen-free extract & 41.57 & 69.34 \\
Ash & 13.58 & 3.84 \\
Tabulated nutritive value/kg DM & & \\
TDN, \% & 45 & 65 \\
DCP, \% & 10 & 12 \\
ME/MJ & 1.67 & 2.41 \\
\hline Not
\end{tabular}

Note: aData from National Academy of Sciences. ${ }^{15}$

Abbreviations: CFM, concentrated feed matter; DM, dry matter; TDN, total digestible nutrients; DCP, digestible crude protein; ME, metabolizable energy; MJ, megajoules.

Parnell Lab, Aust) 11 days apart. One day after the second cloprostenol injection, ewes were subjected to ultrasound examination for 4 successive days. All animals that responded to the second dose of cloprostenol were included in the results.

\section{Ultrasound examination}

Ovaries were scanned using an ultrasound scanner (100 SL; Pie Medical, the Netherlands). Ewes were scanned in dorsal recumbence to avoid the fat tail. Corpora lutea and follicles were counted and their diameters determined. Preovulatory scans were taken during the first wave following both doses of cloprostenol. The luteal scans were assessed 7 days later to determine the ovulation rate. The number of visible follicles was counted and the follicles grouped, according to their diameter, as small ( $\leq 3 \mathrm{~mm})$, medium $(>3$ to $<5 \mathrm{~mm}$ ), or large ( $\geq 5 \mathrm{~mm}$ ). For determining ovulation rate, the number and diameters of corpora lutea on both ovaries were recorded.

\section{Blood sampling}

Blood samples were collected at the end of the diet restriction interval from all animals in both the control and restricted groups. Blood samples were collected via jugular venipuncture. Blood samples were allowed to clot and sera were separated by centrifugation at 3,000 rpm for 15 minutes. Sera were kept at $-20^{\circ} \mathrm{C}$ until measurement of hormone, blood biochemicals, and antioxidants.

\section{Insulin}

Insulin was assayed using a double-antibody, solid-phase enzyme-linked immunosorbent assay commercial kit (catalog number E29-072; Immunospec, Canoga Park, CA, USA). Sensitivity of the assay was $2.0 \mu \mathrm{IU} / \mathrm{mL}$.

\section{Alkaline phosphatase (ALP)}

ALP changes phenylphosphate to phenol and phosphate. The liberated phenol was measured in the presence of 4-aminophenazone and potassium ferricyanide activity in serum samples was assayed colorimetrically using commercially available reagents (Biodiagnostics, Egypt). For ALP measurement, $0.5 \mathrm{~mL}$ phenylphosphate was added to blood serum $(0.025 \mathrm{~mL})$; then, after 20 minutes' incubation at $37^{\circ} \mathrm{C}, 0.25 \mathrm{~mL}$ of ethylenediaminetetraacetic acid (EDTA) and 4-aminophenazone was added, followed by $0.25 \mathrm{~mL}$ potassium ferricyanide. Color was read at optic density $510 \mathrm{~nm}$ using a spectrophotometer. Results are expressed in IU/L.

\section{Lactate dehydrogenase (LDH)}

$\mathrm{LDH}$ catalyzes the reduction of pyruvate to form lactate and NAD. The catalytic concentration is measured from the rate of decrease of NADH. LDH activity in serum samples was assayed colorimetrically using a commercial kit (Biosystem, S.A., Barcelona, Spain) for LDH measurement, to $20 \mu \mathrm{L}$ serum $1.0 \mathrm{~mL}$ of substrate was added. Color was read at $340 \mathrm{~nm}$ at $0.5,1,2$, and 3 minutes using a spectrophotometer. Results are expressed in U/L.

\section{Total antioxidant capacity (TAC)}

The determination of TAC was estimated by measuring the reaction of antioxidants in the sample with a defined amount of hydrogen peroxide $\left(\mathrm{H}_{2} \mathrm{O}_{2}\right) \cdot{ }^{17}$ The antioxidants in the sample eliminate a certain amount of the provided hydrogen peroxide. The residual $\mathrm{H}_{2} \mathrm{O}_{2}$ was determined colorimetrically by an enzymatic reaction which involves the conversion of 3,5 dichloro-2-hydroxy benzensulphonate to a colored product, which was measured with a spectrophotometer. Results are expressed in $\mathrm{mM} / \mathrm{L}$.

\section{Superoxide dismutase (SOD)}

SOD assay relies on the ability of the enzyme to inhibit the phenazine methosulfate-mediated reduction of nitro blue tetrazolium dye. Results are expressed in $\mathrm{U} / \mathrm{mL}$.

The biochemical parameters glucose and total cholesterol (mg/dL) were performed according to the manufacturer's and resultant color was read by spectrophotometer.

\section{Statistical analysis}

Data are presented as mean \pm standard error of the mean. Statistical analyses of the data were performed using SPSS ${ }^{\circledR}$ software (v 16; SPSS Inc., Chicago, IL, USA). ${ }^{18}$ Data were subjected to independent samples $t$-test to determine the 
effects of treatment (restricted, control) in each breed and simple one-way analysis of variance (ANOVA) was used to study the effect of breed (Barki, Rahmani, Ossimi) within each treatment on the studied parameters. Diameters of the dominant follicles and of the corpora lutea of all control and restricted ewes were subjected to simple one-way ANOVA. Duncan's multiple range test was used to differentiate between significant means, and differences are regarded as significant whenever $P<0.05$. General linear model was processed where univariate ANOVA used a $2 \times 3$ model that included the two treatments (restricted versus control) and three breeds (Rahmani, Barki, and Ossimi) as fixed effects.

\section{Results}

Results of this study revealed that control Barki ewes had significantly more small follicles than control Rahmani and Ossimi ewes (Figure 1). Restricted Barki had significantly fewer small follicles than control Barki $(P<0.01)$, but restricted Rahmani had significantly fewer small follicles than control Rahmani and restricted Ossimi had insignificantly more small follicles than control Ossimi. Within restricted breeds, both Rahmani and Ossimi had more small follicles than Barki. Both control Barki and Rahmani had more medium follicles than control Ossimi. Control Barki $(P<0.01)$ and Rahmani ewes had more medium follicles than restricted Barki and Rahmani ewes, but restricted Ossimi ewes had more medium follicles than their control. There was no significant difference in

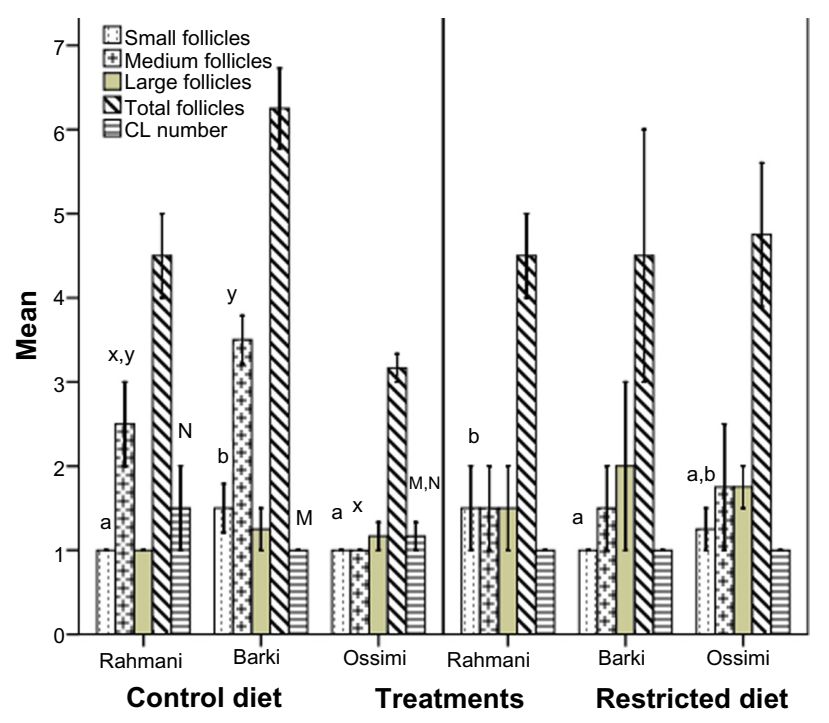

Figure I Mean number of small, medium, large follicles and corpora lutae in control and restricted ewes.

Notes: Values represented are the mean \pm standard error of the mean (error bars) of animals within each treatment of small, medium, large, and total follicles and corpora lutea $(\mathrm{CL})$ (number, ovulation rate). Number of small follicles with different letters $(a, b)$, number of medium follicles with different letters $(x, y)$, and number of $C L$ with different letters $(M, N)$ are significantly different at $P<0.05$. Small follicles were $\leq 3 \mathrm{~mm}$; medium $>3$ to $<5 \mathrm{~mm}$; and large $\geq 5 \mathrm{~mm}$ in diameter. number of medium follicles within restricted breeds. Although difference in number of large follicles was not significant within breed or treatment groups, all restricted ewes had higher large follicle numbers compared to controls (Figure 1). Control Barki and Ossimi ewes had slightly more large follicles than control Rahmani. All restricted breeds had insignificantly more large follicles than their controls. Within restricted breeds, Rahmani ewes had insignificantly fewer large follicles than restricted Barki and Ossimi. The corpus luteum number, which represents ovulation rate, of control Rahmani ewes was significantly higher than that of control Barki $(P=0.002)$ and higher than that of control Ossimi $(P=0.001)$ and Ossimi $(P=0.001)$. Diet restriction had no significant effect on ovulation rate of Barki ewes, but insignificantly decreased ovulation rates of Rahmani and Ossimi ewes. Ovulation rate was similar within all restricted ewes. Restricted Ossimi ewes had significantly $(P=0.04)$ smaller corpus luteum diameters than control Ossimi. Similarly, restricted Rahmani ewes had insignificantly smaller corpus luteum diameters compared to control Rahmani. Similar corpus luteum diameters were observed within Barki ewes (Table 3). Either treatment (0.001) or breed (0.046) affected ovulation rate, but breed significantly $(P=0.05)$ affected the number of small follicles (Table 4). Both treatment and breed tended to have a similar effect on dominant follicle diameter and ovulation rate $(P=0.08)$, and treatment tended to affect the number of medium $(P=0.06)$ and large follicles $(P=0.09)$.

Restriction influenced neither initial nor final body weight in any breed (Figure 2$)$, but did influence $(P<0.0001)$ body weight change and body weight change \% $(P<0.0001)$. Control Rahmani lost less weight and had lower body weight change \% than restricted Rahmani, and restricted Barki lost less weight and had lower body weight change $\%$ than control Barki. Neither body weight change nor body weight change \% of Ossimi ewes was affected by treatment. When age was analyzed as a fixed factor in addition to breed and treatment, age $(P=0.0001)$ and treatment *age $(P=0.016)$ significantly affected final body weight but breed *age tended to affect it $(P=0.065)$. However, without considering age as a fixed factor, both breed and treatment * breed significantly affected body weight change and body weight change $\%$ (Table 4).

Insulin declined insignificantly in all restricted ewes (Figure 3). Neither treatment nor breed affected insulin levels (Table 4). Glucose levels increased in all restricted ewes than control ewes. A significant increase of glucose $(P=0.01)$ occurred in restricted Rahmani ewes, but increases were not significant in restricted Barki or Ossimi ewes (Figure 4). General linear model showed an effect of treatment on 
Table 3 Ovarian DF and CL diameters in diet-restricted and control ewes

\begin{tabular}{|c|c|c|c|c|c|c|}
\hline \multirow{2}{*}{$\begin{array}{l}\text { Breed } \\
\text { Treatment }\end{array}$} & \multicolumn{2}{|l|}{ Rahmani } & \multicolumn{2}{|l|}{ Barki } & \multicolumn{2}{|l|}{ Ossimi } \\
\hline & Control & Restricted & Control & Restricted & Control & Restricted \\
\hline $\mathrm{N}$ & 10 & 10 & 10 & 10 & 9 & 8 \\
\hline Age & $3.3 \pm 0.13$ & $3.2 \pm 0.14$ & $3.7 \pm 0.12$ & $3.7 \pm 0.09$ & $3.3 \pm 0.18$ & $2.4 \pm 0.19$ \\
\hline DF diameter, $\mathrm{cm}$ & $0.65 \pm 0.02$ & $0.61 \pm 0.03$ & $0.61 \pm 0.03$ & $0.67 \pm 0.03$ & $0.63 \pm 0.02$ & $0.6 \mathrm{I} \pm 0.02$ \\
\hline $\mathrm{CL}$ diameter, $\mathrm{cm}$ & $0.81 \pm 0.05^{a}$ & $0.78 \pm 0.03^{a}$ & $0.83 \pm 0.04^{\mathrm{a}, \mathrm{b}}$ & $0.83 \pm 0.05^{\mathrm{a}, \mathrm{b}}$ & $0.93 \pm 0.04^{b}$ & $0.80 \pm 0.04^{a}$ \\
\hline
\end{tabular}

Notes: Means with different superscripts $\left({ }^{\mathrm{a}-\mathrm{b}}\right)$ within breed are significantly different at $P<0.05$. Data is presented as mean \pm standard error of the mean.

Abbreviations: DF, dominant follicle; CL, corpus luteum.

glucose levels ( $P=0.016$ ) (Table 4$)$. Total cholesterol showed a nonsignificant increase in all restricted ewes (Figure 5). Total cholesterol increased in all restricted ewes, but this increase was not significant (Figure 5), and neither treatment nor breed affected its levels.

All restricted ewes had increased concentrations of TAC, but this increase was significant $(P=0.046)$ in Barki ewes only (Figure 6). Moreover, treatment significantly affected TAC ( $P=0.006)$ (Table 4). Generally, SOD levels tended to increase $(P=0.07)$ in all restricted ewes, but the increase in SOD levels was significant $(P=0.03)$ in restricted Rahmani ewes (Figure 7). Breed significantly affected SOD $(P=0.042)$. LDH levels increased in restricted Ossimi and Rahmani ewes, and this increase was significant $(P=0.02)$ in restricted Ossimi, but LDH was nearly similar in restricted Barki (Figure 8). ALP showed a slight decline in levels due to dietary restriction (Figure 9).

\section{Discussion}

\section{Body weight}

Although all breeds studied were fat-tailed, the heavier Rahmani ewes did not adapt to restriction as well as Barki and Ossimi ewes, since the amount of body weight change and the body weight change \% was improved in Barki and nearly similar in Ossimi. This may be explained by the nature of Barki as a desert breed that can withstand longer intervals of adverse environmental conditions and unavailability of high-nutritive ration in addition to their smaller size compared to the other two breeds. Similarly, the Barbarine (fat-tailed) breed is being held in Tunisia can lay down subcutaneous and intramuscular fat from energy surplus and mobilize energy accumulated in the tail when facing feed scarcity. ${ }^{19}$ The decrease in body weight due to $50 \%$ diet restriction in our study was also observed 1 week later when sheep fed $30 \%$ of food intake fed to controls for 35 days. ${ }^{20}$ Similarly, half-maintenance ewes underfed for 27 days presented lower body weight throughout an experiment. ${ }^{21}$ Moreover, llamas that were $40 \%$ and $70 \%$ restricted for 30 days had lower body mass and body condition scores than those in the control group. ${ }^{22}$ In contrast to Barki, Ossimi ewes are large in size with a huge rumen nutrient reservoir and a wider and heavier fat tail, so could withstand restriction for 30 days. In addition, restricted Ossimi were also younger, and this helped them to adapt to diet restriction more efficiently than the other breeds. In agreement with our results, another study reported that age affected body weight loss but not body weight gain in Merino ewes exposed to uncertain feed supply. ${ }^{23}$ The

Table 4 General linear model of effects of breed, treatment, and treatment * breed on ovarian follicles, antioxidants, body weight change, and glucose levels in fat-tailed ewes

\begin{tabular}{lllllll}
\hline Parameters & Corrected model & Intercept & Treatment & Breed & Treatment*breed & $\boldsymbol{R}^{2}$ \\
\hline Small follicles & 0.126 & 0.0001 & 0.915 & 0.050 & 0.273 & 0.075 \\
Medium follicles & 0.094 & 0.0001 & 0.067 & 0.434 & 0.105 & 0.062 \\
Large follicles & 0.338 & 0.0001 & 0.095 & 0.163 & 0.927 & 0.053 \\
Dominant follicle diameter & 0.291 & 0.0001 & 0.585 & 0.606 & 0.088 & 0.059 \\
Number of CL & 0.0001 & 0.0001 & 0.0001 & 0.046 & 0.080 & 0.122 \\
TAC & 0.157 & 0.0001 & 0.006 & 0.772 & 0.967 & 0.155 \\
SOD & 0.073 & 0.0001 & 0.121 & 0.042 & 0.885 & 0.405 \\
Glucose & 0.176 & 0.0001 & 0.016 & 0.539 & 0.499 & 0.172 \\
BWC & 0.0001 & 0.0001 & 0.268 & 0.002 & 0.001 & 0.396 \\
BWC\% & 0.0001 & 0.0001 & 0.160 & 0.007 & 0.002 & 0362 \\
\hline
\end{tabular}

Notes: Treatments were control or restricted diet. Breeds were Rahmani, Barki, and Ossimi. Treatment*breed $=$ two treatments $\times$ three breeds. Small follicles were $\leq 3 \mathrm{~mm}$; medium $>3$ to $<5 \mathrm{~mm}$; and large $\geq 5 \mathrm{~mm}$ in diameter.

Abbreviations: CL, corpora lutea; TAC, total antioxidant capacity; SOD, superoxide dismutase; BWC, body weight change. 


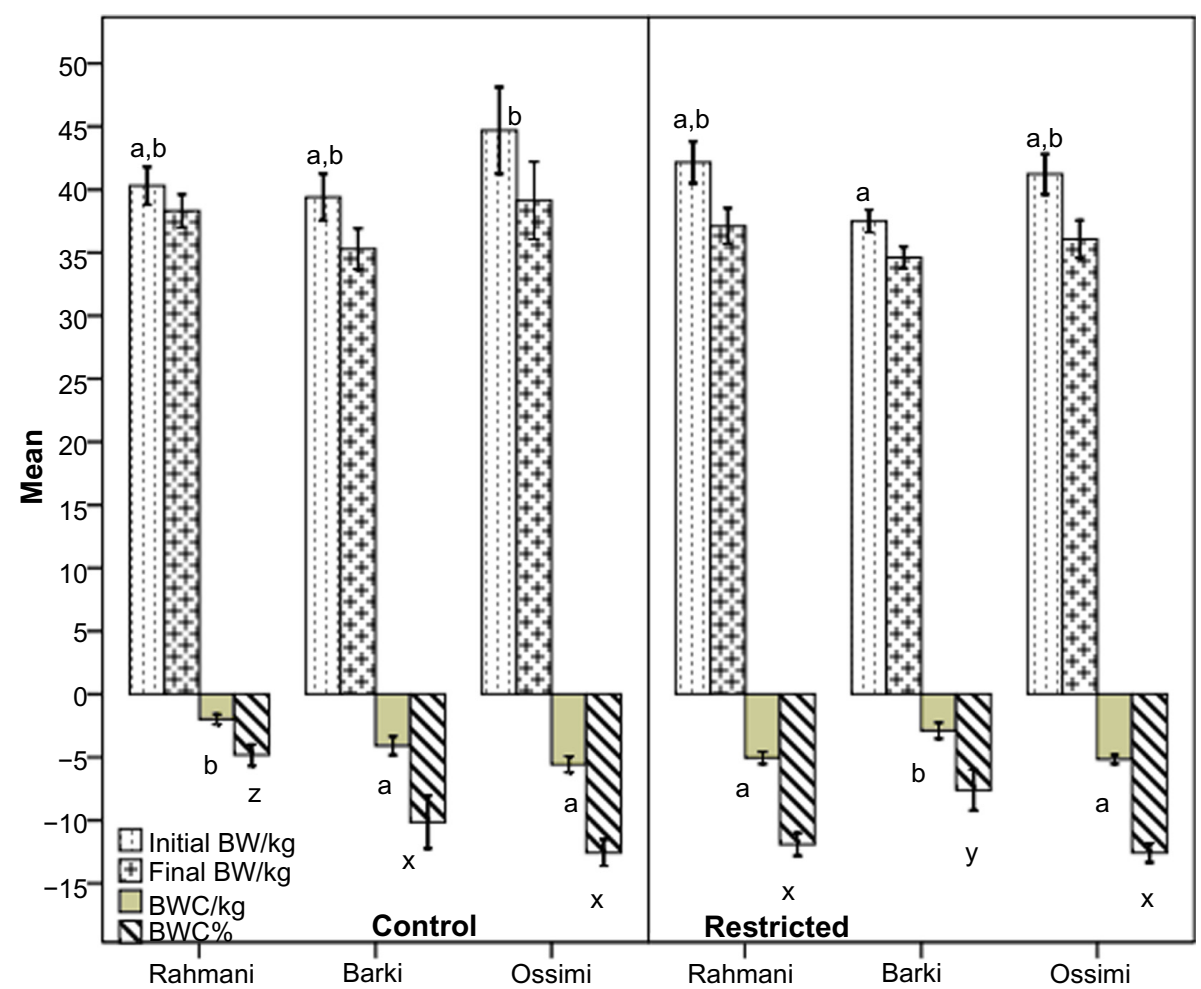

Figure 2 Initial BW, final BW, BWC/kg (final BW - initial BW), and BWC\% (BWC/initial BW $\times 100)$ in control and diet-restricted Barki, Rahmani, and Ossimi ewes. Note: Means with different letters (a,b of $B W C / k g$ and $x, y, z$ of $B W C \%$ ) are significantly different at $P<0.05$.

Abbreviations: BW, body weight; BWC, body weight change.

decrease of body weight and in turn body weight change and body weight change percent whether ewes were control or restricted could be referred to shearing that have been performed after the start of the experiment. Rumen utilizes plant protein to microbial proteins, so reducing

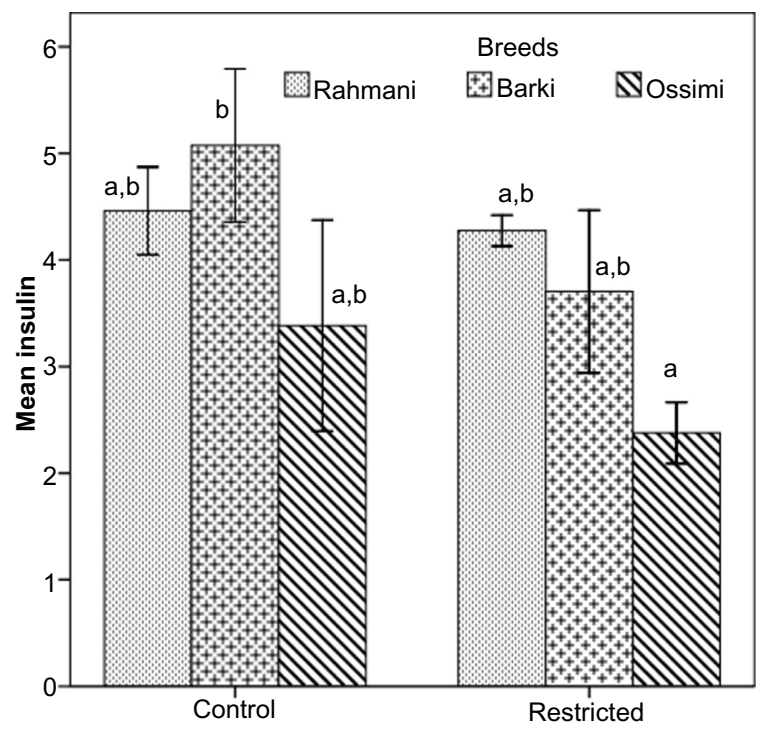

Figure 3 Insulin levels $(\mu \mathrm{lU} / \mathrm{mL})$ in control and diet-restricted Barki, Rahmani, and Ossimi ewes.

Note: Means with different letters $(a, b)$ are significantly different at $P<0.05$. amounts of ration offered to sheep in the current study did not decrease protein requirements but did decrease energy requirements, leading to loss in body weight in treated and control groups. The ewes mobilized their fat depot from their tail to maintain their energy balance, which in turn

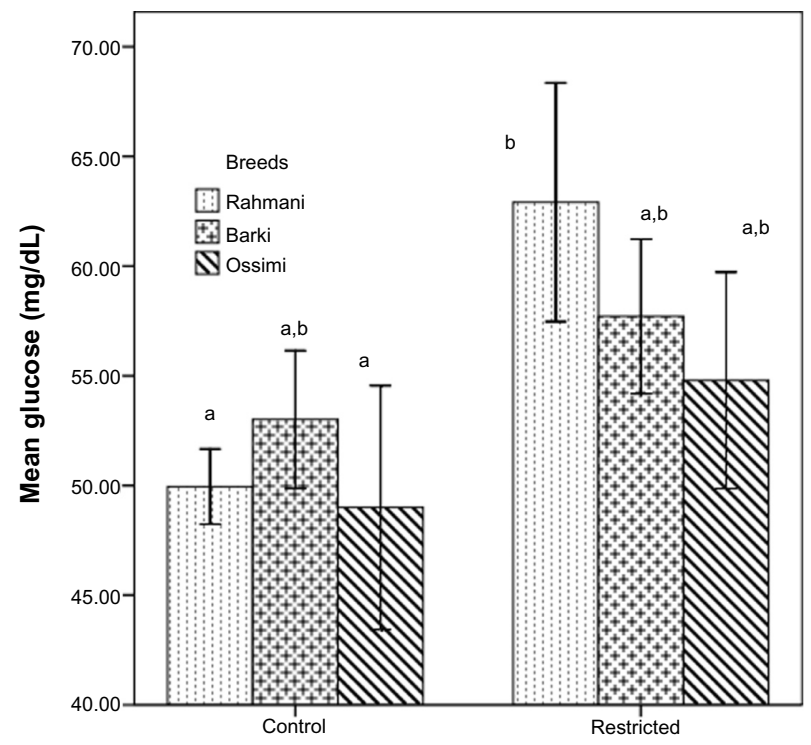

Figure 4 Glucose levels in control and diet-restricted Barki, Rahmani, and Ossimi ewes.

Note: Means with different letters (a,b) are significantly different at $P<0.05$. 


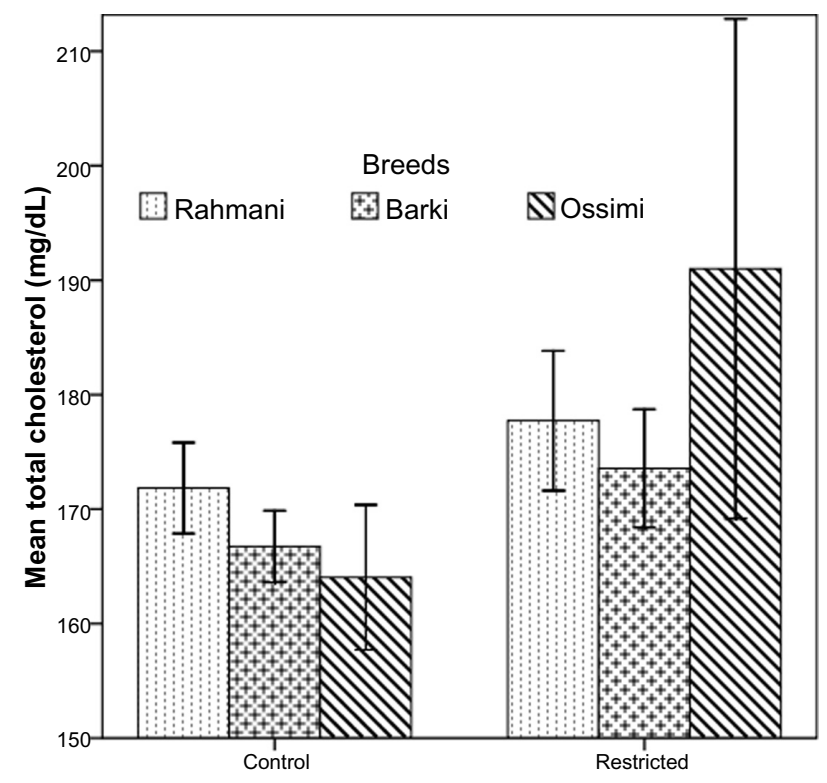

Figure 5 Total cholesterol levels in control and diet-restricted Barki, Rahmani, and Ossimi ewes.

reduced their body weight. The breed differences may also have played a role in the responses of each breed to restriction. Moreover, ewes were fed in groups, so competition and dominance of older ewes led to more energy use during feeding.

\section{Follicle growth and ovulation rate}

A short-term $50 \%$ diet restriction increased the number of small, medium, and large follicles of Ossimi ewes and small and large follicles of Rahmani ewes, but slightly decreased

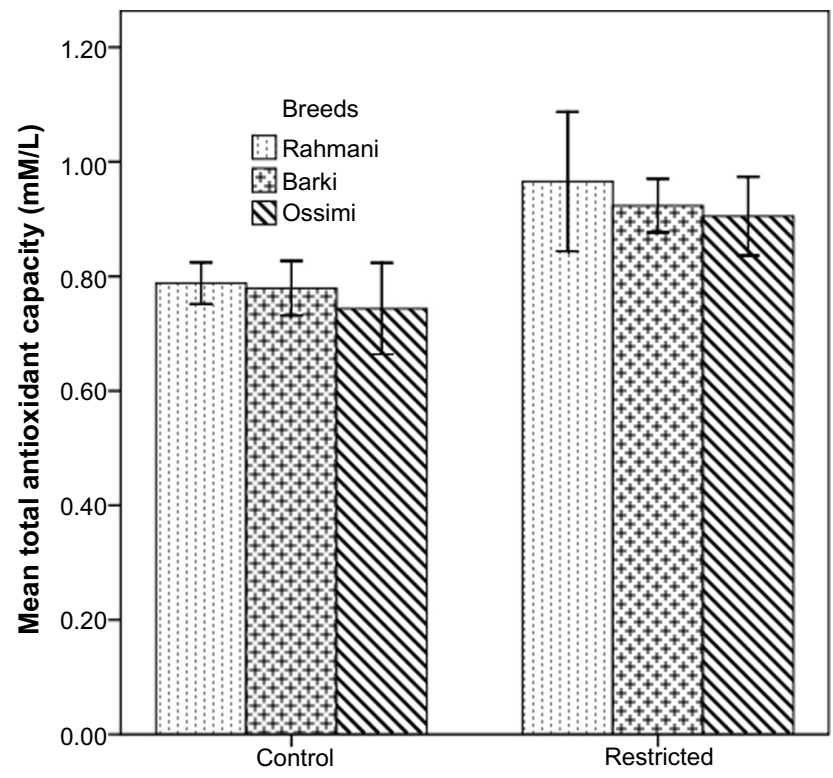

Figure 6 Total antioxidant capacity in control and diet-restricted Barki, Rahmani, and Ossimi ewes.

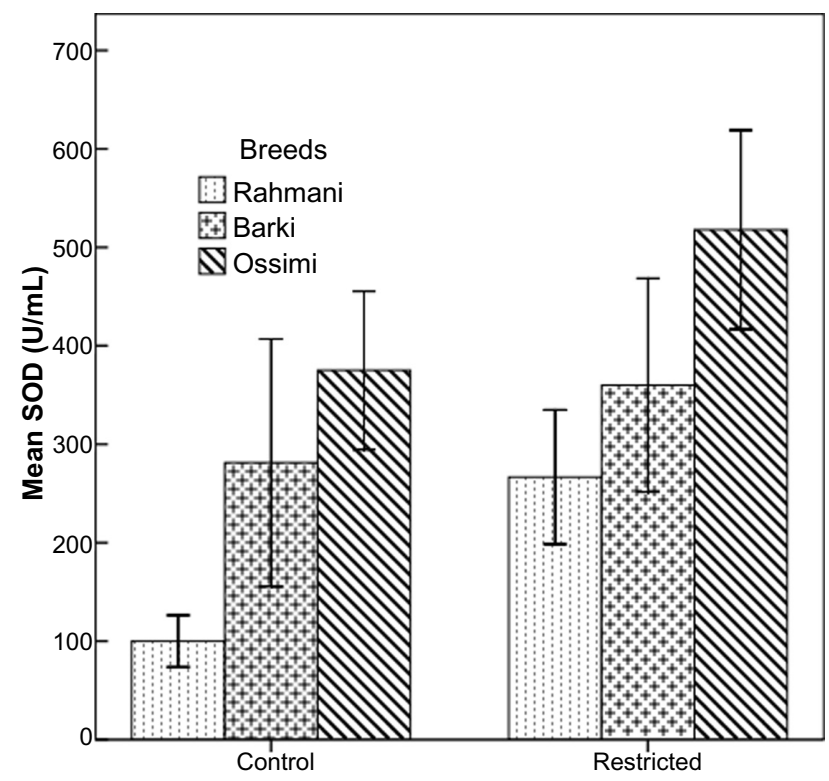

Figure 7 Superoxide dismutase (SOD) levels in control and diet-restricted Barki, Rahmani, and Ossimi ewes.

ovulation rate. In Barki ewes, restriction increased the number of medium and large follicles but did not affect ovulation rate. This may be because of the role of the fat tail in maintaining the animal's condition, whereby ewes can mobilize fat depot when exposed to nutritional stress. ${ }^{13}$ Moreover, the effects of nutrition on gonadotropin release are not very acute unless a severe nutritional restriction occurs in ruminants. ${ }^{24}$ The slight decrease in dominant follicle and corpus luteum diameters observed in 50\% restricted ewes was similar to that observed in llamas fed $40 \%$ and $70 \%$

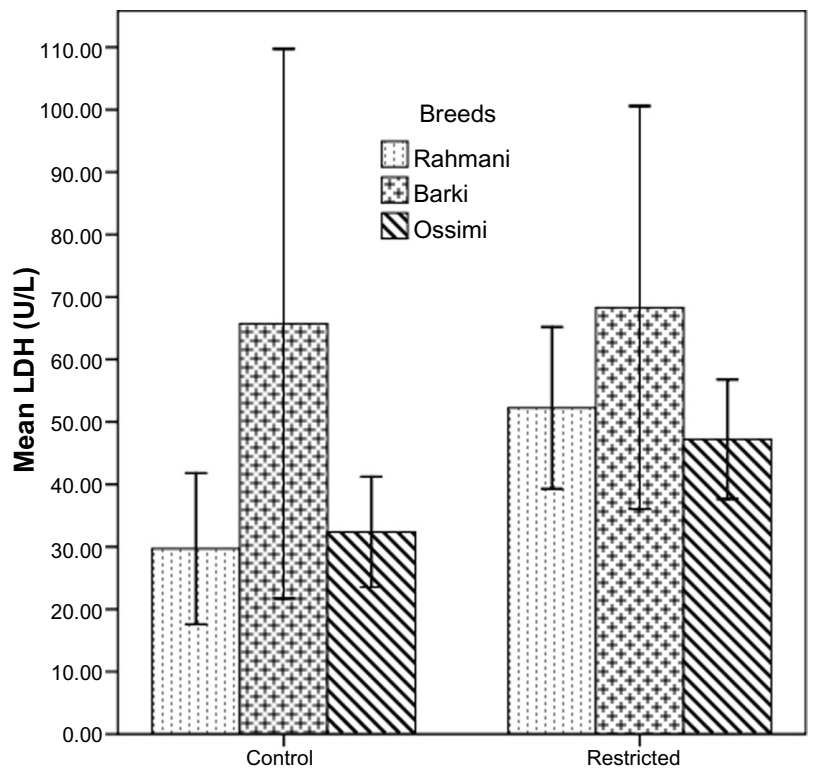

Figure 8 Lactate dehydrogenase (LDH) levels in control and diet-restricted Barki, Rahmani, and Ossimi ewes. 


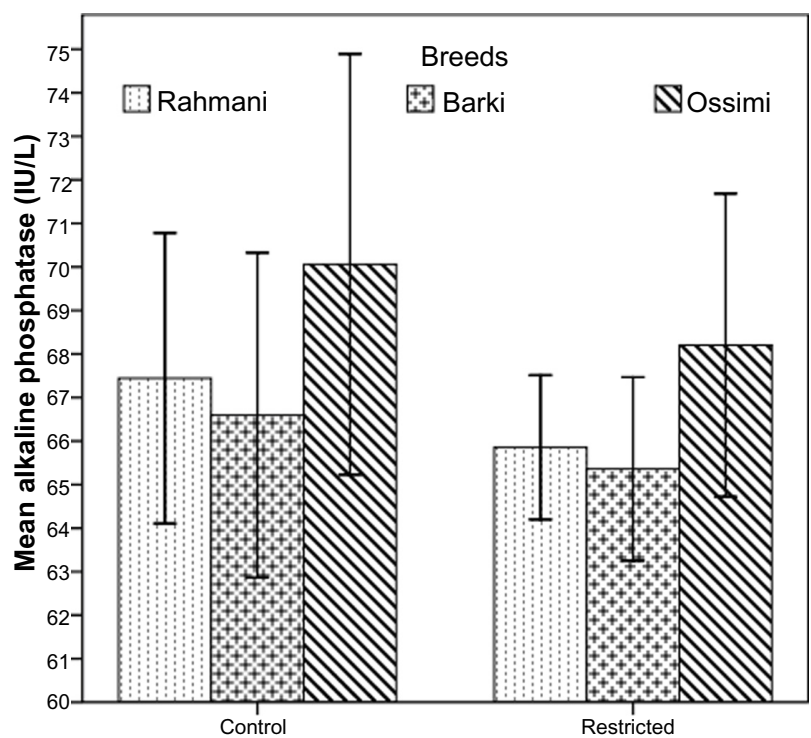

Figure 9 Alkaline phosphatase levels in control and diet-restricted Barki, Rahmani, and Ossimi ewes.

of their maintenance requirements for 30 days $(P<0.05) .^{22}$ Ovulation rate declined significantly due to restriction in both Rahmani and Ossimi ewes in this study, but was not affected by restriction in Barki ewes. Similar to Barki, ovulation rate did not differ between control and fasted ewes. ${ }^{25}$ Adult sheep and cattle seem resistant to such nutritional restraints, perhaps due to ruminal nutrient reservoirs. ${ }^{26}$ In addition to having fat tails, Barki ewes are mainly desert animals accustomed to poor-quality and low quantities of ration. An alternative mechanism of the immediate nutritional effect on follicular growth might involve direct actions at the ovarian level of glucose and metabolic hormones, since glucose transporter proteins and specific receptors for these hormones are present in the follicles..$^{27,28}$ The mechanism by which short-term restriction inhibits folliculogenesis may involve responses to intrafollicular increased estrogen, testosterone, and LDH levels in late-stage follicles, not to variation in intrafollicular insulin level. ${ }^{29}$ This effect may be due to decreased circulating levels of glucose. As follicles became larger, the concentrations of glucose and cholesterol significantly increased, while those of triglycerides, lactate, ALP, and LDH significantly decreased. ${ }^{30}$

\section{Metabolic responses}

\section{Insulin}

The insulin concentration in the blood directly reflects the energy status of the animal to sustain production under extreme environmental conditions. ${ }^{31}$ Dietary energy supply and energy balance have a major impact on reproduction, an effect that is probably mediated by insulin, the principal regulator of energy balance in mammals. ${ }^{7,32}$ Insulin receptors are present in granulosa and theca cells of ovarian follicles. The implication of this is that insulin-mediated glucose uptake in the ovary may modulate follicular function. ${ }^{27,33}$

The three breeds responded to diet restriction directly by decreasing insulin and indirectly by increasing glucose, which suggests either increased synthesis in restricted ewes or the increased utilization of glucose in control ewes. Similarly, the concentration of serum insulin was lower in restricted ewes than in those fed ad libitum. ${ }^{34}$ Moreover, ewes restricted by $30 \%$ for 35 days had low insulin, ${ }^{35}$ while Hu ewes fed a 0.5 -maintenance diet had slightly lower insulin levels compared to controls, ${ }^{29}$ and concentrations of plasma insulin concentrations were lower in low-body condition than in high-body condition ewes during mid-pregnancy. ${ }^{36}$ Overall, there were no main effects on insulin concentrations in ewes that were 50\% restricted for 27 days, although the insulin levels were lower than in controls..$^{21}$ In restricted goats provided with $30 \%$ of their energy requirements for 7 weeks, insulin levels were slightly low during weeks 2 through $7 .^{37}$

\section{Glucose}

Glucose is a major energy source for all cells and tissues, including the ovary, and the uptake of glucose is regulated by metabolic hormones, including insulin. ${ }^{38}$ Glucose availability is a key factor in normal ovarian function, and ruminants derive very little of their glucose from their diet. The ruminant is much more dependent on the biosynthesis of glucose from dietary precursors. The principal precursors for gluconeogenesis are propionic acid, a product of anaerobic fermentation of carbohydrate in the rumen, and gluconeogenic amino acids absorbed from the small intestine..$^{39}$ All restricted ewes among the three breeds had insignificantly high glucose and low insulin, since lowered glucose stimulated insulin secretion and/or reduced pancreatic $\beta$-cell development as a predisposing factor for impaired glucose tolerance ${ }^{40}$ Glucose is transported from the circulation into the follicle along a concentration gradient. ${ }^{41}$ Glucose can then be transported into follicular tissue (theca and granulosa cells) by facilitated diffusion using specific carrier proteins. The net glucose concentration in follicular fluid depends on the rate of diffusion into the follicle and the rate of utilization of glucose by the granulosa cells (glucose consumption). Ovulation rate in ewes appears to be mediated through biological pathways associated with the synthesis and utilization of glucose, ${ }^{42}$ which explains the decline in ovulation in the three breeds studied.

In restricted Rahmani ewes, a significant increase in glucose $(P=0.01)$ was observed, but this increase was not significant in restricted Barki or Ossimi ewes. In agreement with 
our results, Thirone et al found that blood glucose turnover rate was lower $(P<0.001)$ in sheep fed an $82 \%$ maintenance diet for 30 days than in those fed ad libitum. ${ }^{33}$ Similarly, high glucose was recorded in restricted ewes provided with $30 \%$ of intake for 35 days to induce nutritional stress, ${ }^{35}$ while restricted goats provided with $30 \%$ of their energy requirements for 7 weeks had insignificantly high glucose levels from weeks 3 through 5 of the experiment and similar glucose levels during weeks 6 and 7 to controls. ${ }^{37}$

Nutritional restriction, even during a short period, was related to the presence of large follicles in a static growing phase which, despite the animals reaching ovulation, remained static during the induced follicular phase and evidenced functional alterations as there was no inhibition of the development of subordinate follicles. Short-term undernutrition was shown to have deleterious effects on the functionality of preovulatory follicles, which can compromise fertility. ${ }^{8}$

In contrast to these results, glucose concentrations were not affected in ewes by inducing half-maintenance nutritional restriction for 27 days. ${ }^{21}$ In Hu sheep fed 0.5-maintenance for 7 days, from day 6 to day 12 of the estrous cycle after removal of the vaginal pessary, lowered glucose levels were recorded from day 7 to day 10 , but, on day 12 , the glucose level was similar to that of control ewes. ${ }^{29}$

\section{Cholesterol}

The slight increase in cholesterol in all restricted ewes in this study was also found in restricted ewes fed $30 \%$ of intake ${ }^{35}$ and 11 amas $^{22}$ exposed to $40 \%$ and $70 \%$ diet restriction for 35 days.

\section{$\mathrm{LDH}$}

LDH was present in almost all cells and was thought to be a clear indicator of cell destruction. ${ }^{43} \mathrm{LDH}$ activity tended to be increased in atretic follicles, ${ }^{44}$ due to increased release of components from the cellular cytoplasm. Thus, the measurement of LDH activity in follicular fluid is important as a potential index of early follicular degeneration. ${ }^{29} \mathrm{LDH}$ activity was found to reduce in follicular fluid as follicular size increased. ${ }^{30,44}$ LDH levels increased in serum of Rahmani and Ossimi ewes, indicating the increase in tissue destruction and explained that large numbers of follicles grow were atretic, so ovulation rate declined in these two breeds; restricted Barki ewes had low $\mathrm{LDH}$, so no change in their ovulation rate was observed.

\section{ALP}

ALP is a glycoprotein, and this enzyme is produced mainly in the liver, bone, intestine, and placenta, which may contribute to the total circulating amount. ${ }^{45}$ In vivo, ALP plays an important role in intracellular processes significant to cellular differentiation and growth, has been postulated to influence the rate of transport across cell membranes. ${ }^{46}$ The specific function of ALP is not yet known, but the fact that, in mammals, ALP might be involved in intestinal lipid transport ${ }^{47}$ and absorption of fatty acids, carbohydrates, amino acids, and proteins from the intestine ${ }^{48}$ might explain the slight unobserved decrease in ALP levels in all restricted ewes, whatever their breed. In agreement with our results, adult ewes subjected to caloric restriction (25\% maintenance) lost $17 \%$ of their live body weight and plasma ALP fell in restricted sheep than controls. ${ }^{49}$ ALP was not significantly different in $30 \%$ restricted ewes compared to controls. ${ }^{35}$

\section{SOD}

SOD is one of the dependent endogenous antioxidant capacities of the animal that protects cells against toxic and damaging effects of reactive oxygen species. ${ }^{50}$ There is an increased production of superoxide radicals from threshold concentration due to stress conditions imposed either by stress or physiological status (pregnancy/lactation) of an animal. Increased concentrations of SOD were observed with the advancement of pregnancy ${ }^{51}$ and in ewes with medium- to low-quality pastures as the main sources of feed, ${ }^{52}$ indicating that ewes of various ages and body conditions may suffer from oxidative stress during breeding and pregnancy. The present study also found a trend toward increased SOD in diet-restricted groups, indicating that increased oxidative stress in the three breeds of ewes may indirectly affect ovulation rate.

\section{Conclusion}

Diet restriction slightly affected TAC, ovulation rate, and body weight responses, while breed affected small follicle recruitment, ovulation rate, and SOD levels. The nonsignificant change in levels of some markers of energy expenditure, such as insulin, glucose, and cholesterol, were due to the compensatory effects of the fat tail.

\section{Disclosure}

The authors report no conflicts of interest in this work.

\section{References}

1. Martin GB, Rodger J, Blache D. Nutritional and environmental effects on reproduction in small ruminants. Reprod Fertil Dev. 2004;16(4): 491-501.

2. Schneider JE. Energy balance and reproduction. Physiol Behav. 2004;81(2):289-317. 
3. Mackey DR, Wylie AR, Sreenan JM, Roche JF, Diskin MG. The effect of acute nutritional change on follicle wave turnover, gonadotropin, and steroid concentration in beef heifers. J Anim Sci. 2000;78(2): 429-442.

4. Smith JF. Influence of nutrition on ovulation rate in the ewe. Aust J Biol Sci. 1988;41(1):27-36.

5. Forcada F, Abecia JA. The effect of nutrition on the seasonality of reproduction in ewes. Reprod Nutr Dev. 2006;46(4):355-365.

6. Scaramuzzi RJ, Campbell BK, Downing JA, et al. A review of the effects of supplementary nutrition in the ewe on the concentrations of reproductive and metabolic hormones and the mechanisms that regulate folliculogenesis and ovulation rate. Reprod Nutr Dev. 2006;46(4): 339-354.

7. Downing JA, Scaramuzzi RJ. Nutrient effects on ovulation rate, ovarian function and the secretion of gonadotrophic and metabolic hormones in sheep. J Reprod Fertil Suppl. 1991;43:209-227.

8. Sosa C, Gonzalez-Bulnes A, Abecia JA, Forcada F, Meikle A. Short-term undernutrition affects final development of ovulatory follicles in sheep synchronized for ovulation. Reprod Domest Anim. 2010;45(6):1033-1038.

9. Yen HW, Jakimiuk AJ, Munir I, Magoffin DA. Selective alterations in insulin receptor substrates-1, -2 and -4 in theca but not granulosa cells from polycystic ovaries. Mol Hum Reprod. 2004;10(7):473-479.

10. Downing JA, Scaramuzzi RJ. The effect of the infusion of insulin during the luteal phase of the oestrous cycle on the ovulation rate and on plasma concentrations of LH, FSH, and glucose in ewes. Theriogenology. 1997;47(3):747-759.

11. Youngman LD. Protein restriction $(P R)$ and caloric restriction $(C R)$ compared: effects on DNA damage, carcinogenesis, and oxidative damage. Mutat Res. 1993;295(4-6):165-179.

12. Filaire E, Rouveix M, Massart A, Gladine C, Davicco MJ, Durand D. Lipid peroxidation and antioxidant status in rat: effect of food restriction and wheel running. Eur J Appl Physiol. 2009;107(2):243-250.

13. Alves SP, Bessa RJ, Quaresma MA, et al. Does the fat tailed Damara ovine breed have a distinct lipid metabolism leading to a high concentration of branched chain fatty acids in tissues? PLoS One. 2013;8(10):e77313.

14. Khachadurian AK, Adrouni B, Yacoubian H. Metabolism of adipose tissue in the fat tail of the sheep in vivo. J Lipid Res. 1966;7(3): $427-436$.

15. National Academy of Sciences. Nutrient Requirements of Sheep. 6th ed. Washington, DC: National Academy Press; 1985.

16. Heuzé V, Tran G, Bastianelli D, Boudon A, Lebas F. Berseem (Trifolium alexandrinum) [webpage on the Internet]. Feedipedia.org. A programme by INRA, CIRAD, AFZ and FAO; 2014 [updated April 11, 2014]. Available from: http://www.feedipedia.org/node/248. Accessed.

17. Koracevic D, Koracevic G, Djordjevic V, Andrejevic S, Cosic V. Method for the measurement of antioxidant activity in human fluids. J Clin Pathol. 2001;54(5):356-361.

18. Statistical Package for the Social Sciences. Version 16. Chicago, IL: SPSS Inc.; 2007.

19. Ben Salem H, Lassoued N, Rekik M. Merits of the fat-tailed Barbarine sheep raised in different production systems in Tunisia: digestive, productive and reproductive characteristics. Trop Anim Health Prod. 2011;43(7):1357-1370.

20. Sejian V, Maurya VP, Naqvi SM. Adaptability and growth of Malpura ewes subjected to thermal and nutritional stress. Trop Anim Health Prod. 2010;42(8):1763-1770.

21. Sosa C, Abecia AJ, Carriquiry M, et al. Early pregnancy alters the metabolic responses to restricted nutrition in sheep. Domest Anim Endocrinol. 2009;36(1):13-23

22. Norambuena MC, Silva M, Urra F, et al. Effects of nutritional restriction on metabolic, endocrine, and ovarian function in llamas (Lama glama). Anim Reprod Sci. 2013;138(3-4):252-260.

23. Rose G, Kause A, Mulder HA, et al. Merino ewes can be bred for body weight change to be more tolerant to uncertain feed supply. J Anim Sci. 2013;91(6):2555-2565.
24. O'Callaghan D, Yaakub H, Hyttel P, Spicer LJ, Boland MP. Effect of nutrition and superovulation on oocyte morphology, follicular fluid composition and systemic hormone concentrations in ewes. J Reprod Fertil. 2000;118(2):303-313.

25. Kiyma Z, Alexander BM, Van Kirk EA, Murdoch WJ, Hallford DM, Moss GE. Effects of feed restriction on reproductive and metabolic hormones in ewes. J Anim Sci. 2004;82(9):2548-2557.

26. Tatman WR, Judkins MB, Krysl LJ, Moss GE. Gastrointestinal digesta passage and fermentation patterns associated with restricted intake of a low-quality forage in ewes. Small Rumin Res. 1991;4(4):393-399.

27. Williams SA, Blache D, Martin GB, Foot R, Blackberry MA, Scaramuzzi RJ. Effect of nutritional supplementation on quantities of glucose transporters 1 and 4 in sheep granulosa and theca cells. Reproduction. 2001;122(6):947-956.

28. Munõz-Gutiérrez M, Blache D, Martin GB, Scaramuzzi RJ. Ovarian follicular expression of mRNA encoding the type 1 insulin like growth factor receptor IGF-IR and insulin like growth factor binding protein 2 IGFBP2 in anoestrous sheep after 5 days of glucose, glucosamine or supplementary feeding with lupin grain. Reproduction. 2004;128(6):747-756.

29. Ying S, Wang Z, Wang C, et al. Effect of different levels of short-term feed intake on folliculogenesis and follicular fluid and plasma concentrations of lactate dehydrogenase, glucose, and hormones in Hu sheep during the luteal phase. Reproduction. 2011;142(5):699-710.

30. Nandi S, Kumar VG, Manjunatha BM, Gupta PS. Biochemical composition of ovine follicular fluid in relation to follicle size. Dev Growth Differ. 2007;49(1):61-66.

31. Sejian V, Srivastava RS, Varshney VP. Pineal-adrenal relationship: modulating effects of glucocorticoids on pineal function to ameliorate thermal-stress in goats. Asian-Australas J Anim Sci. 2008;21(7): 988-999.

32. Butler WR. Nutritional interactions with reproductive performance in dairy cattle. Anim Reprod Sci. 2000;60-61:449-457.

33. Thirone AC, Huang C, Klip A. Tissue-specific roles of IRS proteins in insulin signaling and glucose transport. Trends Endocrinol Metab. 2006;17(2):72-78.

34. Sano HA, Takebayashi Y, Kodama K, et al. Effects of feed restriction and cold exposure on glucose metabolism in response to feeding and insulin in sheep. J Anim Sci. 1999;77(9):2564-2573.

35. Sejian V, Maurya VP, Naqvi SM. Adaptive capability as indicated by endocrine and biochemical responses of Malpura ewes subjected to combined stresses (thermal and nutritional) in a semi-arid tropical environment. Int J Biometeorol. 2010;54(6):653-661.

36. Verbeek E, Oliver MH, Waas JR, McLeay LM, Blache D, Matthews LR. Reduced cortisol and metabolic responses of thin ewes to an acute cold challenge in mid-pregnancy: implications for animal physiology and welfare. PLoS One. 2012;7(5):e37315.

37. Tanaka T, Fujiwara K, Kim S, Kamomae H, Kaneda Y. Ovarian and hormonal responses to a progesterone-releasing controlled internal drug releasing treatment in dietary-restricted goats. Anim Reprod Sci. 2004;84(1-2):135-146.

38. Rabiee AR, Lean IJ. Uptake of glucose and cholesterol by the ovary of sheep and cattle and the influence of arterial LH concentrations. Anim Reprod Sci. 2000;64(3-4):199-209.

39. Overton TR, Drackley JK, Ottemann-Abbamonte CJ, Beaulieu AD, Emmert LS, Clark JH. Substrate utilization for hepatic gluconeogenesis is altered by increased glucose demand in ruminants. J Anim Sci. 1999; 77(7):1940-1951.

40. Husted SM, Nielsen MO, Tygesen MP, Kiani A, Blache D, Ingvartsen KL. Programming of intermediate metabolism in young lambs affected by late gestational maternal undernourishment. Am J Physiol Endocrinol Metab. 2007;293(2):E548-E557.

41. Józwik M, Józwik M, Teng C, Battaglia FC. Concentrations of monosaccharides and their amino and alcohol derivatives in human preovulatory follicular fluid. Mol Hum Reprod. 2007;13(11):791-796.

42. Teleni E, Rowe JB, Croker KP, Murray PJ, King WR. Lupins and energy-yielding nutrients in ewes. II. Responses in ovulation rate in ewes to increased availability of glucose, acetate and amino acids. Reprod Fertil Dev. 1989;1(2):117-125. 
43. Franke RP, Fuhrmann R, Mrowietz C, Rickert D, Hiebl B, Jung F. Reduced diagnostic value of lactate dehydrogenase (LDH) in the presence of radiographic contrast media. Clin Hemorheol Microcirc. 2010;45(2-4):123-130.

44. Wise T. Biochemical analysis of bovine follicular fluid: albumin, total protein, lysosomal enzymes, ions, steroids and ascorbic acid content in relation to follicular size, rank, atresia classification and day of estrous cycle. J Anim Sci. 1987;64(4):1153-1169.

45. Weiss MJ, Ray K, Henthorn PS, Lamb B, Kadesch T, Harris H. Structure of the human liver/bone/kidney alkaline phosphatase gene. J Biol Chem. 1988;263(24):12002-12010.

46. Lobel BL, Tic L, Shelesnyak MC. Studies on the mechanism of nidation. XVII. Histochemical analysis of decidualization in the rat. Acta Endocrinol (Copenh). 1965;50(4):469-485.

47. Van Hoof VO, De Broe ME. Interpretation and clinical significance of alkaline phosphatase isoenzyme patterns. Crit Rev Clin Lab Sci. 1994;31(3):197-293.
48. Wada H, Yagami I, Niwa N, Hayakawa T, Tsuge H. Distribution and properties of rat intestinal alkaline phosphatase isoenzymes. Exp Anim. 2001;50(2):153-158.

49. Prickett TC, Ryan JF, Wellby M, et al. Effect of nutrition on plasma C-type natriuretic peptide forms in adult sheep: evidence for enhanced C-type natriuretic peptide degradation during caloric restriction. Metabolism. 2010;59(6):796-801.

50. Miller JK, Brzezinska-Slebodzinska E, Madsen FC. Oxidative stress, antioxidants, and animal function. J Dairy Sci. 1993;76(9) 2812-2823.

51. Pathan MM, Latif A, Hemen D, Siddique GM, Vadodaria VP. Antioxidant status in periparturient Mehsana buffaloes. Rev Vet 2009;21(1):748-751.

52. Bernabucci U, Ronchi B, Lacetera N, Nardone A. Markers of oxidative status in plasma and erythrocytes of transition dairy cows during hot season. J Dairy Sci. 2002;85(9):2173-2179.

\section{Publish your work in this journal}

Open Access Animal Physiology is an international, peer-reviewed, open access journal publishing original research, reports, reviews and commentaries on all areas of animal physiology. The manuscript management system is completely online and includes a very

\section{Dovepress}

quick and fair peer-review system. Visit http://www.dovepress.com/ testimonials.php to read real quotes from published authors. 